\title{
Discussion on How to Create Higher Vocational Education Practice-Based Teaching Systems Adapted to Vocational Skills Competitions
}

\author{
Jinzhi Zhang \\ Rizhao Polytechnic, Shandong, China \\ Email:mlbsabc@sina.com
}

How to cite this paper: Zhang, J.Z. (2018) Discussion on How to Create Higher Vocational Education Practice-Based Teaching Systems Adapted to Vocational Skills Competitions. Open Journal of Social Sciences, 6, 95-101.

https://doi.org/10.4236/jss.2018.62009

Received: January 17, 2018

Accepted: February 10, 2018

Published: February 13, 2018

Copyright $\odot 2018$ by author and Scientific Research Publishing Inc. This work is licensed under the Creative Commons Attribution International License (CC BY 4.0).

http://creativecommons.org/licenses/by/4.0/

cc) (i) Open Access

\begin{abstract}
In recent years, with the economic level constantly improving in China, people have their living standards greatly improved, and higher demands have been raised on education. Higher vocational colleges are important bases for cultivating talents in the country and important places for students to study. Gradually the practice-based teaching in such colleges has been attracting eyeballs of and concerned about by educational authorities in the country. More and more attentions are paid to vocational skills competitions in colleges, and increasing numbers of students turn to the competitions, which whether seeing from educational philosophy or students' overall qualities will help colleges to achieve the goals of cultivating talents. Surveys on higher vocational colleges show, most of such colleges are focused on what textbooks offer and theoretical knowledge in teaching, however, the theoretical knowledge is almost separated from practices. Most are still poor in the practice-based teaching system, and consequently most students have no practical experience and innovative abilities in practical work, and get low scores in vocational skills competitions, which is a main problem existing in the practice-based teaching system in such colleges. To create practice-based teaching systems adapted to vocational skills competitions in college teaching is to cultivate students' abilities of practical operation so as to enable them to combine theories with practices on the basis of what they have learned and apply what they have gotten in professional work. This article first analyzes the patterns of vocational skills competitions, followed by the problems arising the practice-based teaching in colleges; finally, it shows how to create practice-based teaching systems in colleges adapted to vocational skills competitions.
\end{abstract}

\section{Keywords}

Vocational Skills Competition, Higher Vocational Colleges, Practice-Based 
Teaching

\section{Introduction}

The operation of vocational skills competitions has to some extent promoted students' enthusiasm in learning, based on the competitions, and teaching reform in higher vocational colleges is a basic pattern to improve students' vocational skills and cultivate professional talents in such colleges. With the educational undertakings continuously renovated and innovated, educational philosophy is also changing [1]. Higher vocational colleges, as important bases for talents training, aimed to improve students' professional skills whose ultimate goal is to serve the people and society and at the same time raise students' value. Seen from education, to combine the practice-based teaching system and vocational skills competitions in colleges and cultivate students in professional skills as planned will raise teaching guarantee in higher vocational colleges while promoting students' practical abilities and experience. On the basis of vocational skills competitions, to cultivate students' practical experience can well raise students' abilities in self-learning and improvement, which can help solve the problems arising in practice. Practical experiences are becoming more and more important in the modern career development, which can provide more professional and better service to the society, following the basic needs of the developing era.

\section{Vocational Skills Competitions Pattern}

Vocational skills competitions are generally sponsored by state educational authorities, belonging to a state level category I competitions, and the vocational skills competitions are also known as national vocational colleges skills competitions, seen from category, it belongs to professional competitions. The vocational skills competitions are generally held by state educational authorities together with the Ministry of Finance, people's governments and human resources departments. After years of development and reforms, the vocational skills competitions have been gradually popularized to almost all provinces and cities. At present, the vocational skills competitions have become the most influential professional knowledge and skills competitions which attract the max number of students and cover the most skills and have the largest influences in education circle, attracting the eyeballs of more and more colleges. Seen from technical philosophy, the development and innovation of vocational skills competitions have promoted the innovation and development of higher vocational teaching modes. Seen from the talent cultivation, the vocational skills competitions help higher vocational colleges establish talents cultivating strategies with goals as planned. The vocational skills competitions whether in the college teaching system reform or students' career development plans, both bring a positive effect [2]. 
As of 2013, 12 provinces and cities had held vocational skills competitions in China, with the continuous improvement on the professional skills competition system, gradually different professional knowledge and skills are increased, such as mechanical process and control, CNC machine maintenance, financial management, human resources management, sports skills, etc. More and more students start to be included in the professional competitions, according to the latest provisions of vocational skills competitions, the competitions are divided into theoretical knowledge and skills test and practical skills test. Generally theoretical knowledge and skills test belongs to closed book exam, whose questions will be at randomly selected in the exam bank; or the questions will be made by professional and technical personnel. During the examinations, students can as a team take exams according to provinces or cities; the competition is divided into secondary vocational college group and higher vocational college group. On the basis of vocational skills competitions, students will be trained through practice-based teaching, through learning and competitions, they can learn more about current social demands, make scientific and reasonable study plans, besides, they may know that the practice-based teaching is an important part of college teaching, what modern society needs are more than professional skills, in addition, higher requirements have been raised to college students in the overall quality and ability.

\section{Problems Arising in the College Practice-Based Teaching}

With the living levels improved continuously, people have renewed their understanding of education; more and more students have accessed higher education. Surveys show, as of the end of 2014, there had been 20 million students or more learning in higher vocational colleges in China. Educational authorities in the country had released policies to support and encourage the college education. The teaching level and quality in colleges are also gradually becoming focuses of the social fields. Higher vocational colleges mainly teach students through class teaching. Therefore, the teaching staffs in colleges take a dominant position in teaching. However, surveys show the disqualification of some teachers in professional skills and the lack of practice-based teaching have lowered students' classroom learning effect and the students have no accumulations of practical learning, and the practice-based teaching systems in colleges are far to be perfect. At present, the traditional educational modes in colleges have many problems. In teaching, more attentions are paid to theoretical knowledge and the teachings are only based on textbooks. In addition, no theoretical knowledge is combined with practical problems in teaching as a result, students do not know how to deal with problems in work after graduation, who are difficult to independently seek and deal with problems, which is the main drawback of the traditional education. The teaching staffs in colleges have important influences on the teaching effect. To strengthen the practice-based teaching of teaching staffs in colleges can have class teaching quality improved, helping students better un- 
derstand what they have learned and master professional contents through class teaching [3].

Surveys are conducted on the teaching quality of the teaching staffs in colleges. It is found that at present more than $50 \%$ of teaching staffs in colleges are college students who have just finished their studies in the country, the students after graduation serve as teachers, having no any experience in teaching and being in the lack of practice-based teaching. According to most students, the teachers who have just graduated only make simple explanations and analysis according to textbooks while teaching professional knowledge, doing little in deep-level analysis and expansions of what are taught, which seriously affect students' understanding of professional knowledge, making it difficult for students to master professional knowledge that they learn. For the teacher who have just graduated got little knowledge about practice-based teaching when studying in colleges, they know little about the practice-based teaching. Besides, they make no special analysis on the key points and difficult points in the professional knowledge, as a result, the teaching effect are severely affected, which have lowed students' enthusiasm in learning. In the survey, it is also found that not only such teachers have this problem, some experienced teachers in colleges also have a series of problems such as textbook-based teaching, lack of practice-based teaching, single teaching methods, which makes it hard to attract students in class teaching, and the boring teaching contents fail to stimulate students' enthusiasm in learning. All of such problems will affect students to master and understand what they learn in class teaching. Teachers are required to add some practice-based teaching knowledge in class teaching, combining theoretical knowledge with practical experience so as to help students understand abstract professional knowledge. Through the practice-based teaching mode, students can get professional knowledge easily and have their memories of knowledge deepened and class teaching efficiency improved [4].

\section{Create a College Practice-Based Teaching System Adapted to Skills Competitions}

\subsection{Set up Scientific and Rational Educational Philosophy and Improve College Teachers' Practice-Based Teaching Experience}

In the past years, in order to cultivate talents, great efforts have been made in the country to support talents training in colleges. The practice-based teaching can train college students in practical operation, improve students' thinking modes, helping to raise college students' overall levels and comprehensive qualities. Practice-based teaching is an important teaching mode in colleges, which consists of course experimental teaching and course design. Educational authorities proposed in 2012: In order to improve students' comprehensive qualities and skills, first of all, traditional teaching modes must be renovated, and teaching contents be reformed, and college students shall receive practice-based teaching 
according to needs of social development. Based on vocational skills competitions, it is required to create a scientific and reasonable practice-based teaching system in colleges. First, it needs to set up a scientific and rational educational philosophy, increase college teachers' experience in practice-based teaching. Colleges shall reform original teaching patterns, push the college laboratory construction, and teachers shall be encouraged to adopt practice-based teaching modes to increase the teaching experience and class teaching effect. In order to raise college teachers' practice-based teaching abilities, they are required to own solid professional knowledge with practical abilities improved so as to better combine professional knowledge and practical experience, as well as basic theories and practices.

Those who are poor in practice-based teaching should be trained specially and be assessed in a regular period, and those who fail to pass the assessment will be punished. For teachers who just graduated from colleges, their teaching abilities and practice-based teaching experience shall be strictly assessed before they start teaching, requirements on teaching shall be raised and more attentions shall be paid to teachers' practice-based teaching skills. In order to improve college teaching levels, the faculty team construction is a decisive factor, in order to raise teachers' professional practice-based teaching, teachers shall have their titles strictly assessed. The ultimate goal of practice-based teaching assessment on college teachers is to make them be faced with different practice-based teaching tasks independently and train students' practice-based teaching skills through the practice-based teaching. During the teaching, it needs to combine theoretical knowledge and practices in order to enable students to better understand and master the professional knowledge they learn. To improve college teachers' practice-based teaching experience is an important method to guarantee class teaching efficiency and also a good way to push the faculty team construction in colleges.

\subsection{Push the Practice-Based Teaching Reform on the Basis of Career Planning}

Most knowledge contents in the vocational skills competitions are randomly selected from state questions banks, and some are made by professional teachers. The results of such competitions may indicate what college students have mastered and their overall quality. Based on such competitions, college practice-based teaching systems shall be renovated and improved, first, students shall be instructed to set up a career planning philosophy based on which practice-based teaching renovation and innovation will be conducted. Students' career planning can help them confirm what level they are in, better understand what they can do and clearly get their strengths and weaknesses, assess what they have owned to set a suitable height of their own, and then go down to earth to achieve the goals and plans they set through hard working. Students' career planning and practice-based teaching interact with each other. Through the ac- 
cumulations of practical experience in learning, students can understand what they have mastered and what stage they are in and also make sure of the goals of future career planning. The career planning can help college students avoid tortuous paths in the future development and some risks, to develop a scientific and effective way and set a planning and analysis for the future are also foundations and preconditions for the practice-based teaching renovation.

For the career planning philosophy started quite late in the country, besides, the practice-based teaching reform was also raised by educational scholars in recent years, which have resulted that the educational philosophy of educational reforms in parts of colleges fail to keep up with the times. Based on vocational skills competitions, the reforms of practice-based teaching systems in colleges should take additional course training of career planning into consideration, and main courses shall be based on practical experience, aimed to cultivate students' practice-based experience and enhances their vocational skills. During the teaching, college teachers should enable students to set up a long-term goal and plan and renovate teaching contents and forms. First, make students know what career planning is based on, extra-curricular training shall be provided to students, which are expected to play an active role in helping students' career planning [5].

\subsection{Design Teaching Programs Combined with Vocational Skills Competitions on the Basis of Competence Training}

Vocational skills competitions get involved in many professional fields, which are also orientations of current social development and demands for talents. Based on vocational skills competitions in teaching, it is to cultivate students' practical skills and improve their comprehensive qualities, which is thought an opportunity for college talents cultivation. In order to create practice-based teaching systems adapted to vocational skills competitions in colleges, during the teaching, all shall be based on competence training, and make teaching programs be combined with vocational skills competitions. Based on the competence training, first, it needs to change original teaching modes and methods, and make students form a vocational education-orientated philosophy in colleges and increase their interests and hobbies in learning. Generally vocational skills competitions will simulate actual work circumstances, during the exams, candidates are required to complete tests according to actual needs of work. In order to create teaching programs combined with vocational skills competitions, students in teaching should be specially trained on how to analyze and deal with problems. During the teaching, teachers can adopt scene teaching modes into which students are required to work and feel the atmosphere and circumstances in the actual operation. With regard to the scene teaching, first of all, teachers shall develop a clear plan and then arrange work tasks to students according to actual needs of the work, after the tasks are completed by students, teachers take charge of check and assessment, showing any shortcoming in time and giving 
suggestions. The scene teaching modes mean that targeting competence training, vocational education is orientated to renovate original teaching modes, create teaching programs combined with vocational skills competitions in order to increase students' practice-based experience.

\section{Conclusion}

To create a practice-based teaching system in colleges adapted to vocational skills competitions is a new teaching philosophy and also a trend of educational development in the future. In order to combine vocational skills competitions with the practice-based teaching system in colleges, first, it needs to set up a scientific and rational educational philosophy and improve teachers' practice-based teaching experience in colleges; second, practice-based teaching shall be renovated on the basis of career planning; in the meantime, teaching programs combined with vocational skills competitions shall be created on the basis of competence training.

\section{Funding}

2017 Shandong Teaching Reform Task: Studies on Vocational Skills Competitions Promoting Higher Vocational Education, Teaching \& Reform; Task Code: 2017JZ10.

\section{References}

[1] Li, Y.C. and Kong, L.H. (2017) Studies on Nationwide Vocational Colleges Skills Competitions Promoting Practice-Based Teaching Systems in College Engineering Measurement Technology Specialty. Bulletin of Surveying and Mapping, No. 9, 145-149.

[2] Hou, X.Y., Wang, W.N. and Li, X.L. (2016) Create a Practice-Based Teaching System Adapted to Vocational Skills Competitions. Times Agricultural Machinery, 43, $132+134$.

[3] Guo, N. and Zhang, X.T. (2016) Philosophy Studies on Vocational Skills Training-Based Practice-Based Teaching Systems in Higher Vocational Colleges. Education Forum, No. 21, 136-137.

[4] Fan, L., Ai, M.M. and Yu, M. (2016) Create a Practice-Based Teaching System in Higher Vocational Colleges Combined with Vocational Skills Competitions. Shandong Industrial Technology, No. 3, 184.

[5] Zhang, Q. (2015) Create a Practice-Based Teaching System of International Commerce Specialty in Higher Vocational Colleges on the Basis of Vocational Skills Competitions. Science \& Technology Vision, No. 7, $36+43$. 